\title{
Evaluation of TPF versus Gefitinib in Residual or Recurrent or Metastatic (R/R/M) Head and Neck Carcinoma
}

\author{
Manas Dubey*, Faraz Khan, Rajeev Atri, Vivek Kaushal, Anil k Dhull, Rakesh Dhankhar \\ Department of Radiation Oncology, Regional Cancer Centre, Pt. BD Sharma Postgraduate Institute of Medical \\ Sciences, Rohtak, Haryana, India
}

*Corresponding Author: Manas Dubey, Department of Radiation Oncology, Regional Cancer Centre, Pt. BD Sharma Postgraduate Institute of Medical Sciences, Rohtak, Haryana, India, Email:drmanas001@gmail.com

\begin{abstract}
Background: To compare triple agent chemotherapy (docetaxel, carboplatin, 5-fu) versus single agent Targeted therapy (gefitinib) in head and neck squamous cell carcinomas, having post radiation, residual, recurrent or metastatic disease.

Materials and Methods: Sixty histopathologically proven patients for squamous cell carcinoma of LAHNC with residual, recurrent or metastatic head and neck squamous cell cancer who were previously treated (as a combination of surgery and/or radiation therapy with/without concomitant chemotherapy) and are eligible for palliative chemotherapy/targeted therapy were randomly allocated to the study by draw of lots, 30 in Group I and 30 in Group II. Group I patients received inj. docetaxel $80 \mathrm{mg} / \mathrm{m} 2 \mathrm{iv}$, inj. carboplatin $300 \mathrm{mg}$ $/ \mathrm{m} 2$ and inj.5-fu $600 \mathrm{mg} / \mathrm{m} 2$ ivinfusion. This regimen was repeated every 3 weeks for 6 cycles (total duration of chemotherapy 15 weeks). Group II patients received oral tablet gefitinib 250mg daily for 3 weeks followed by clinical plus biochemical assessment and commencement of next cycle for 6 cycles (total duration of chemotherapy 15 weeks).
\end{abstract}

Results and Conclusion: In terms of response rate, patients belonging to TPF group have higher partial response which is $33.3 \%$ as compared to $10 \%$ in gefitinib arm, and this result is statistically significant $(p=0.049)$. Similarly; progression free survival and overall survival was higher in TPF group as compared to oral targeted therapy group with gefitinib.

Keywords: Residual, Recurrent, Metastatic, TPF, Gefitinib, PFS, OS.

\section{INTRODUCTION}

Head and neck squamous cell carcinoma (HNSCC) develops from the mucosal linings of the upper aero-digestive tract, comprising oral cavity, oropharynx, hypopharynx, larynx, nasopharynx, nasal cavity and paranasal sinuses. Worldwide newly diagnosed cases of head and neck cancer in 2012 were 599,637 which was $4.2 \%$ of all cancers. Deaths due to head and neck cancer were 324,834 which was $4 \%$ of all cancers. The age standardized incidence for head and neck cancers were 12.6 per 100,000 males and 3.7 per 100,000 females. [1] In India alone, 2.5 lakhs new patients of head and neck carcinoma are diagnosed every year, of whom about three-fourths are in an advanced stage. [2] According to the recently published "Million deaths study", it is one of the commonest malignancies in India and is responsible for $22.9 \%$ of cancer related mortality. [3]
Locally advanced head and neck cancers include AJCC stage III or IV (T3-4 and/or N1-3, M0) disease at diagnosis. Approximately $70-80 \%$ of these patients are diagnosed with locally advanced disease and 30-50\% with lymph node involvement. [4] In spite of the relatively good prognosis of the patients with early head and neck cancer treated by standard therapy (surgery or radiotherapy), the prognosis is significantly worse for patients with locally advanced head and neck cancer (LAHNC), with less than 30\% of those being cured. [5] In LAHNC, surgery without adjuvant radiotherapy is associated with very poor cure rates. Compared with surgery alone, adjuvant radiotherapy resulted in an approximately $10 \%$ absolute increase in 5-year cancer specific survival and overall survival for patients with lymph node-positive head and neck squamous cell carcinoma (HNSCC). [6] Moreover, many locally advanced cases may 
even not be amenable to surgery either because of complications or sequelae of surgery. So radiotherapy preferably with chemotherapy remains the mainstay of treatment for LAHNC. $[7,8]$

The recurrence rates in the surgically treated patients range between $2-10 \%$ for the No neck, $8-15 \%$ for $\mathrm{N} 1$ disease, and $10-30 \%$ for $\mathrm{N} 2$ disease. In multiple nodes and multiple levels, the neck control is less than 30\%. The recurrence rate of $70 \%$ or more in this situation is reduced to $20 \%$ or less with the postoperative irradiation. [9]

In LAHNC (stage III and IV), combined surgery and radiotherapy still give poor survival due to the propensity for local recurrence (upto 50\%) and distant metastatic spread (approximately 10$30 \%$ ). [10] Chemotherapy has been added to standard therapy in recent years in order to improve the curability of these advanced lesions.

Most patients with residual or recurrent or metastatic $(\mathrm{R} / \mathrm{R} / \mathrm{M})$ disease only qualify for palliative treatment. Treatment options in these patients include supportive care only, or in addition single-agent chemotherapy, combination chemotherapy or targeted therapies either alone or in combination with cytotoxicagents. Treatment choice should be based on factors such as performance status (PS), co-morbidity, prior treatment, symptoms, patient preference and logistics. [11]

A large number of conventional single agents have been investigated in the past in patients with $\mathrm{R} / \mathrm{R} / \mathrm{M}-\mathrm{SCCHN}$. The four most active and most extensively used agents are taxanes, platinum compounds and 5-fluorouracil (5-FU). These drugs produce a response of short duration, $\sim 3-5$ months, in $15 \%-30 \%$ of cases and only rarely complete response (CR). [12] The taxanes are among the highest scoringagents, with response rates varying between $20 \%$ and $43 \%$. Taxanes stabilizes and protect microtubules against disassembly. Cells treated with taxanes have difficulty with the spindle assembly, cell division and also chromosome segregation. Palliative chemotherapy consisting of cetuximab, cisplatin and infusional $5 \mathrm{FU}$ is regarded as the standard of care in head and neck cancers. [13]

Head and neck squamous cell carcinoma (HNSCC) is frequently seen in the lower socioeconomic strata of the society in lesser developed countries. Consequently, cetuximabbased combination chemotherapy is received by less than $1 \%$ of the eligible patients. TPF regimen, which consists of docetaxel, cisplatin and infusional 5-FU, has become the new standard for induction chemotherapy in the loco-regionally advanced disease setting since the publication of the TAX323/EORTC24971 (Europe) and TAX324 studies (USA). [14] There is a temptation to use this regimen or other three-drug regimens also in the recurrent or metastatic disease setting. Janiniset al observed an overall response rate of $44 \%$, a median time to progression of 7.5 months and a median OS of 11 months. [14] About three fourth of the head and neck cancer patients in India, present in stage III or IV where the treatment of choice is concomitant chemoradiation or radiation alone depending on the condition of the patients. Though some percent of patients are cured, most present with residual, recurrent or metastatic disease and need salvage chemotherapy. Platins, 5fluorouracil, cetuximab, taxanes, methotrexate, gemcitabine, gefitinib, capecitabine, vinorelbine are chemotherapeutically effective drugs in residual, recurrent or metastatic head and neck cancers with response rate varying from 10$44 \%$. Combination chemotherapy is more effective than single agent chemotherapy but is sometimes not tolerated by patients because of poor nutritional status and general condition of the patients

Some studies have shown that single agent or double agent chemotherapy may have similar role as triple agent chemotherapy while preserving quality of life. In view of above, a study has been planned to compare triple agent chemotherapy (docetaxel, carboplatin, 5-fu) versus single agent Targeted therapy (gefitinib) in head and neck squamous cell carcinomas, having post radiation, residual, recurrent or metastatic disease.

\section{Material AND Methods}

A prospective randomized single-center parallel comparative study was conducted at Department of Radiotherapy, Regional Cancer Centre, Pt B D Sharma Post-Graduate Institute of Medical Science, Rohtak. Institutional Board of postgraduate studies approved the protocol for the study.

Sixty histopathologically proven patients for squamous cell carcinoma of LAHNC (stage IIIIV as per American Joint Committee on Cancer 7th edition, 2010) were enrolled for the study after obtaining informed written consent. The patients were randomly allocated to the study by 
draw of lots, 30 in Group I and 30 in Group II. Inclusion Criteria included patients with residual, recurrent or metastatic head and neck squamous cell cancer who are previously treated (as a combination of surgery and/or radiation therapy with/without concomitant chemotherapy) and are eligible for palliative chemotherapy/targeted therapy. Patients who have received radical EBRT (as curative radiation therapy) or palliative EBRT, with or without concomitant chemotherapy earlier. Karnofsky Performance Status $\geq 70$. Complete hemogram with $\mathrm{Hb}>8 \mathrm{gm} / \mathrm{dL}$; TLC $>4000 / \mathrm{cmm}$, Platelet count $>100,000 / \mathrm{cmm}$, renal function tests with Blood urea $<40 \mathrm{mg} / \mathrm{dL}$ and Serum creatinine $<1.5 \mathrm{mg} / \mathrm{dL}$. Liver function tests with SGOT < $35 \mathrm{IU} / \mathrm{L}$ and SGPT < $40 \mathrm{IU} / \mathrm{L}$ of head and neck. Patients who sign the informed consent and are ready to be on follow up as required.

\subsection{Treatment}

Group Iconsists of 30 previously treated patients (as a combination of surgery or radiation therapy with/without concomitant chemotherapy) with residual, recurrent or metastatic head and neck squamous cell carcinoma. This group received injdocetaxel 80 $\mathrm{mg} / \mathrm{m} 2$ iv, inj.carboplatin $300 \mathrm{mg} / \mathrm{m} 2$ and inj.5fu $600 \mathrm{mg} / \mathrm{m} 2$ ivinfusion. This regimen was repeated every 3 weeks for 6 cycles (total duration of chemotherapy 15 weeks). The intent of treatment was to deliver minimum 6 cycles of chemotherapy.

Group II consists of 30 previously treated patients (as a combination of surgery or radiation therapy with/without concomitant chemotherapy) with residual, recurrent or metastatic head and neck squamous cell carcinoma. This group received oral tablet gefitinib $250 \mathrm{mg}$ daily for 3 weeks followed by clinical plus biochemical assessment and commencement of next cycle for 6 cycles (total duration of chemotherapy 15 weeks).

From the commencement of treatment, all the patients included in the study were carefully and regularly assessed during treatment at three weekly interval during treatment. Tumor response (both primary and nodal response) was assessed by WHO response criteria. The primary end point will be progression free survival (PFS). The PFS will be calculated in days from the date of randomization to the date of progression. The overall survival was calculated in days from the date of randomization to the date of death or the last date of known contact. In both the groups, the patients were followed up 3 weekly till completion of 6 cycles and thereafter at monthly interval for 6 months. At every visit, each patient was clinically evaluated for local control of disease and treatment related complications. The patients were assessed for any evidence of distant metastasis during each follow up.

Statistical analysis was done applying Chisquare test.

\section{ReSults}

The baseline characteristics of patients including demographic profiles, stages etc. are given in table1.

\begin{tabular}{|c|c|c|c|}
\hline \multicolumn{2}{|c|}{ Patients } & $\begin{array}{c}\text { Group I, } \\
\text { n (\%) }\end{array}$ & $\begin{array}{c}\text { Group II, } \\
\text { n }(\%)\end{array}$ \\
\hline \multicolumn{2}{|l|}{ Number } & $30(100)$ & $30(100)$ \\
\hline \multicolumn{2}{|l|}{ Males } & $30(100)$ & $29(96.7)$ \\
\hline \multicolumn{2}{|l|}{ Smokers } & $30(100)$ & $30(100)$ \\
\hline \multicolumn{2}{|c|}{ Alcoholics } & $26(86.7)$ & $20(66.7)$ \\
\hline \multirow{3}{*}{$\begin{array}{l}\text { KPS } \\
\text { Score }\end{array}$} & 70 & $13(43.3)$ & $13(43.3)$ \\
\hline & 80 & $12(40)$ & $12(40)$ \\
\hline & 90 & $5(16.6)$ & $5(16.6)$ \\
\hline \multirow{5}{*}{$\begin{array}{l}\text { Site of } \\
\text { tumor }\end{array}$} & Oral Cavity & $3(10)$ & $4(13)$ \\
\hline & Hypopharynx & $3(10)$ & $3(10)$ \\
\hline & Oropharynx & $18(60)$ & $18(60)$ \\
\hline & Nasopharynx & 0 & $1(3.3)$ \\
\hline & Larynx & $06(20)$ & $4(13)$ \\
\hline \multirow{2}{*}{$\begin{array}{l}\text { Previous } \\
\text { mode of } \\
\text { treatment }\end{array}$} & Curative & $07(23.3)$ & $17(56.7)$ \\
\hline & Palliative & $23(76.7)$ & $13(43.3)$ \\
\hline \multirow[t]{2}{*}{ Stage } & III & $06(20)$ & $12(40)$ \\
\hline & IV & $24(80)$ & $18(60)$ \\
\hline \multirow{3}{*}{$\begin{array}{l}\text { Previous } \\
\text { treatment } \\
\text { received }\end{array}$} & \begin{tabular}{|l} 
Radiation \\
alone
\end{tabular} & $12(40)$ & $20(66.67)$ \\
\hline & $\begin{array}{l}\text { Radiation with } \\
\text { chemotherapy }\end{array}$ & $16(53.3)$ & $10(33.3)$ \\
\hline & $\begin{array}{l}\text { Radiation with } \\
\text { surgery }\end{array}$ & $02(6.7)$ & 0 \\
\hline
\end{tabular}

Both the groups were comparable with regard to age, sex, and clinical stage $(\mathrm{p}>0.05)$. The median age in group I and II were respectively 55 and 59 years. All efficacy analyses were done on an intent-to-treat basis. All patients had stage III or IV cancer at the time of presentation.

\subsection{Tumor Response}

The responses in accordance to WHO response criteria for solid tumors in group I and II are shown in Table 1.0 and Fig 1.0. Partial response was seen in $33.3 \%$ in group I patients and $10 \%$ in group II patients. In group I and group II stable disease was noted in $23.3 \%$ and $23.3 \%$ patients respectively. Progressive disease was highest in group II patients (66.7\%) and $43.3 \%$ in group I. Complete response was seen in just 1-patient belonging to group I. Result of partial response was statistically significant $(\mathrm{p}=0.049)$. 
Evaluation of TPF versus Gefitinib in Residual or Recurrent or Metastatic (R/R/M) Head and Neck Carcinoma

Table 1.0

\begin{tabular}{|l|c|c|c|}
\hline \multicolumn{1}{|c|}{ Response } & $\begin{array}{c}\text { Group I } \\
(\mathbf{n = 3 0 )} \mathbf{N o} \\
\text { of patients } \\
(\mathbf{\%})\end{array}$ & $\begin{array}{c}\text { Group II } \\
(\mathbf{n = 3 0 )} \text { No. } \\
\text { of patients } \\
(\boldsymbol{\%})\end{array}$ & $\begin{array}{c}\text { p } \\
\text { value }\end{array}$ \\
\hline $\begin{array}{l}\text { Complete } \\
\text { Response (CR) }\end{array}$ & 0 & 0 & 0.216 \\
\hline $\begin{array}{l}\text { Partial } \\
\text { Response (PR) }\end{array}$ & $10(33.3 \%)$ & $3(10 \%)$ & 0.049 \\
\hline $\begin{array}{l}\text { Stable disease } \\
(\text { SD) }\end{array}$ & $7(23.3 \%)$ & $7(23.3 \%)$ & 1.00 \\
\hline $\begin{array}{l}\text { Progressive } \\
\text { disease (PD) }\end{array}$ & $13(43.3 \%)$ & $20(66.7 \%)$ & 0.069 \\
\hline
\end{tabular}

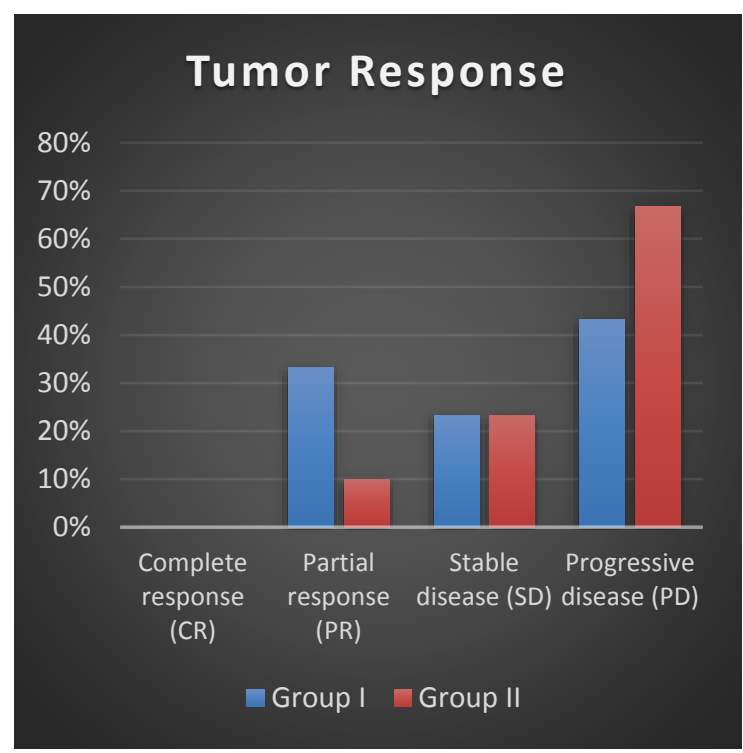

Fig 1.0

\subsection{Progression Free Survival}

Progression free survival (PFS) has been shown in Table 2.0 and fig 2.0. Median PFS was 161 and 100 days in group I and II respectively. Graph has been shown in fig. I Results are statistically significant $(\mathrm{p}<0.001)$.

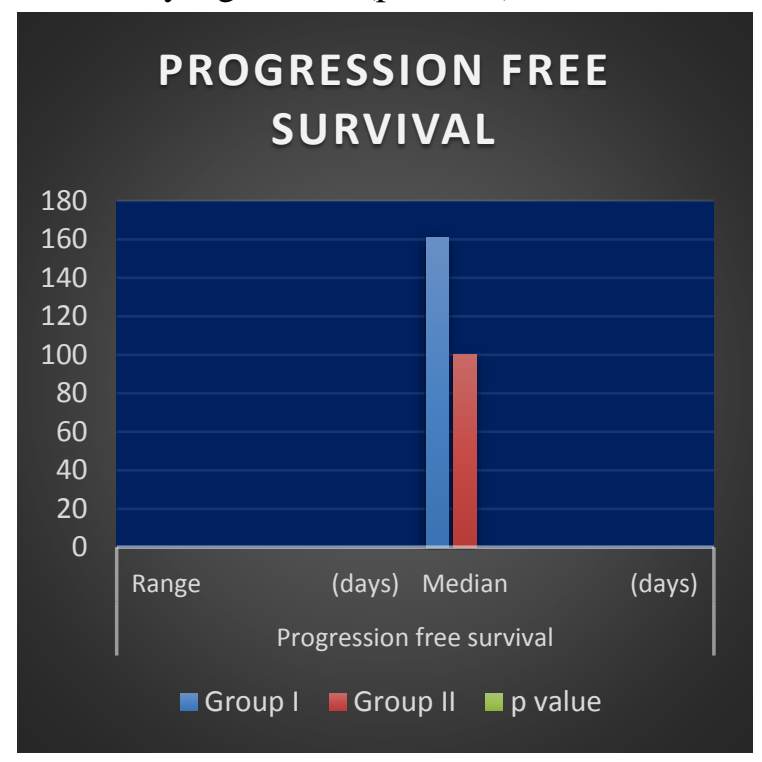

Fig 2.0
Table 2.0

\begin{tabular}{|l|l|l|l|l|}
\hline & & Group I & Group II & p value \\
\hline $\begin{array}{l}\text { Progression } \\
\text { free survival }\end{array}$ & $\begin{array}{l}\text { Range } \\
\text { (days) }\end{array}$ & $65-336$ & $44-208$ & $<0.001$ \\
\hline & $\begin{array}{l}\text { Median } \\
\text { (days) }\end{array}$ & 161 & 100 & \\
\hline
\end{tabular}

\subsection{Overall Survival}

Overall survival (OS) has been shown in Table 3.0. Median overall survival was 168 and 120 days in group I and group II respectively. Graph has been shown in Fig. 3.0. Results are statistically significant $(\mathrm{p}<0.001)$

Table 3.0

\begin{tabular}{|l|l|l|l|l|}
\hline & & $\begin{array}{c}\text { Group } \\
\text { I }\end{array}$ & $\begin{array}{c}\text { Group } \\
\text { II }\end{array}$ & $\begin{array}{c}\text { p } \\
\text { value }\end{array}$ \\
\hline $\begin{array}{l}\text { Overall } \\
\text { Survival }\end{array}$ & Range(days) & $88-336$ & $55-244$ & $<0.001$ \\
\hline & $\begin{array}{l}\text { Median } \\
\text { (days) }\end{array}$ & 168 & 120 & \\
\hline
\end{tabular}

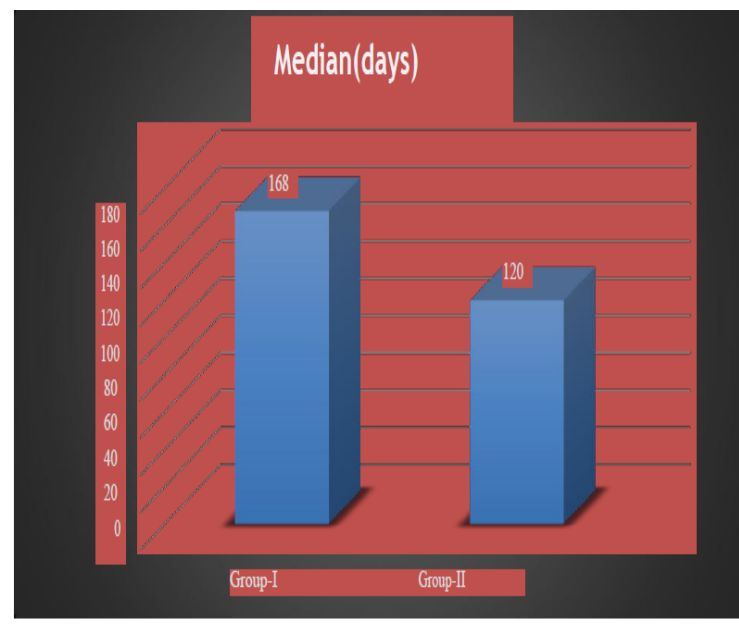

Fig 3.0

\section{DISCUSSION}

The present study was carried out on sixty previously treated, histopathologically proven patients of residual, recurrent or metastatic squamous cell carcinoma of head and neck (AJCC stage III and IV), that were unsuitable for loco- regional treatment and were eligible for palliative chemotherapy. The present prospective, randomized, comparative open label parallel study was carried out to evaluate the feasibility, efficacy and tolerability in terms of survival, local control of two schedules i.e. triple agent (docetaxel, carboplatin and 5fluorouracil i.e. (TPF) versus targeted agent (gefitinib). Partial response (PR) was noted in $33.3 \%$ and $10 \%$ of patients of group I and II respectively which was statistically significant $(\mathrm{p}=0.049)$. Stable disease (SD) was observed in $23.3 \%$ patients of group I and II respectively. In group I and II, progressive disease was found in 
$43.3 \%$ and $66.7 \%$ of patients respectively. The overall response rate in TPF arm group I in our study was $33.3 \%$ which was similar to studied conducted by Koussis et al [15] (25\%) and Guordila et al [16] (27\%). Hitt et al demonstrated the overall response rate to be $42 \%$ which may be attributable to difference in sample size, socioeconomic status, quality of life and performance status of the patients. The overall response in Targeted therapy with Gefitinib group II was $10 \%$ which was comparable with the results mentioned by Cohen et al. [17-18] In accordance to WHO response criteria for solid tumors, no patient did show a complete response in both the group, which was similar to results by Koussis et al. [15] Progression free survival (PFS) in group I and group II was respectively as follows: median 161 days (5.3 months); range 65-336 days, median 100 days (3.3 months); range 44208 days. The difference in PFS between group I and II was statistically significant in our study $(\mathrm{p}<0.01)$. Baghi et al [19] and cohen et al [18] also mentioned results similar to our study. Overall survival (OS) in triple agent group I (TPF) versus Targeted therapy group II (Gefitinib) was respectively as follows: median 168 days (5.6 months); range 88-336 days, median 120 days (4 months); range 55-244 days respectively. The difference in overall survival amongst the two groups was statistically significant ( $\mathrm{p}$ value $=<0.01$ ). Hitt et al [20] and Athnassios et al [21] also mentioned results similar to our study.

In this study the overall survival (OS) was higher in TPF based group than oral gefitinib based group.

\section{CONCLUSION}

The present study was conducted to determine feasibility, efficacy and tolerability of two schedules i.e. triple agent (docetaxel, carboplatin \& 5- fluorouracil) versus oral targeted therapy with gefitinib. Statistics regarding response rate, progression free survival, overall survival, types and frequency of toxicities have been reported. The intended treatment was completed in $46.7 \%$ in both the groups. In terms of response rate, patients belonging to TPF group have higher partial response which is $33.3 \%$ as compared to $10 \%$ in gefitinib arm, and this result is statistically significant $(\mathrm{p}=0.049)$, similarly; progression free survival and overall survival was higher in TPF group as compared to oral targeted therapy group with gefitinib.

\section{REFERENCES}

[1] Ferlay J, Soerjomataram I, Ervik M, Dikshit R, Eser S, Mathers C, et al. Cancer incidence and mortality worldwide: sources, methods and major patterns in GLOBOCAN 2012. Int $\mathrm{J}$ Cancer.2015; 136:E359-86.

[2] Sharma M, Madan M, Manjari M, Bhasin TS, Jain S, Garg S. Prevalence of Head and Neck Squamous Cell Carcinoma (HNSCC) in our population: The clinic-pathological and morphological description of 198 cases. International Journal of Advanced Research2015; 1:827-33.

[3] Dikshit R, Gupta PC, Ramasundarahettige C, Gajalakshmi V, Aleksandrowicz L, Badwe R, et al. Cancer mortality in India: a nationally representative survey. Lancet.2012; 379:180716.

[4] Stupp R, Weichselbaum RR, Vokes EE. Combined modality therapy of head and neck cancer. SeminOncol.1994; 21:349-58.

[5] Parkin DM, Bray F, Ferlay J, Pisani P. Global Cancer Statistic 2008. CA Cancer J Clin. 2010; 55:74-108.

[6] Lavaf A, Genden EM, Cesaretti JA, Packer S, Kao J. Adjuvant radiotherapy improves overall survival for patients with lymph node-positive head and neck squamous cell carcinoma. Cancer. 2008; 112(3):535-43.

[7] Perez CA, Carmichael T, Devineni VR. Carcinoma of the tonsillar fossa: A nonrandomized comparison of irradiation alone or combined with surgery: Long-term results. Head Neck1991; 13:282-90.

[8] Mendenhall WM, Morris CG, Amdur RJ, Hinerman RW, Malyapa RS, Werning JW, et al. Definitive radiotherapy for tonsillar squamous cell carcinoma. Am J ClinOncol.2006; 29(3):290-7.

[9] Byers RM. Modified neck dissection. A study of 967 cases from 1970 to 1980 . American Journal 1986; 150:44-421.

[10] Liggett WJ, Forastiere AA. Chemotherapy advances in head and neck oncology. SeminSurgOncol 1995; 11:265-71.

[11] National Comprehensive Cancer Network. NCCN Clinical Practice Guidelines in Oncology. Head and Neck Cancers.v.2-2017. Fort Washington, Pennsylvania: National Comprehensive Cancer Network; 2017.

[12] Colevas AD. Chemotherapy options for patients with metastatic or recurrent squamous cell carcinoma of the head and neck. J Clin Oncol. 2006; 24:2644-52.

[13] Vermorken JB, Mesia R, Rivera F, Remenar E, Kawecki A, Rottey S, et al. Platinum-based chemotherapy plus cetuximab in head and neck cancer. N Engl J Med.2008; 359:1116-27. 
[14] Janinis J, Papadakou M, Xidakis E, Boukis H, Poulis A, Panagos G, et al. Combination chemotherapy with docetaxel, cisplatin, and 5fluorouracil in previously treated patients with advanced/recurrent head and neck cancer: a phase II feasibility study.Am J Clin Oncol_2000;23:128-31.

[15] Koussis H, Scola A, Bergamo F, et al. Weekly Docetaxel as second line (palliative) chemotherapy in recurrent/metastatic head and neck squamous cell carcinoma (SCCHN). J Clin Oncol. 2007; 25:13-16.

[16] Guordila E, Peyrade F, Chaigneua L, et al. Results of a randomized phase II study comparing Docetaxel with Methotrexate in patients with Recurrent Head and neck cancer. Europe J Cancer. 2004; 40: 2071-76.

[17] Cohen EE, Rosen F, Stadler WM et al. Phase 2 trial of ZD1839 in recurrent or metastatic squamous cell carcinoma of head and neck. J Clin Oncol. 2003a; 21:1980-7.
[18] Cohen EEW, Stenson K, Gustin DM et al. A phase II study of $250 \mathrm{mg}$ Gefitinib (ZD 1839) monotherapy in recurrent or metastatic squamous cell carcinoma of head and neck. J Clin Oncol2003b; 22:502.

[19] Baghi M, Hambek M, Wagenblast J et al. A phase II trial of docetaxel,cisplatin and 5fluorouracil in patients with recurrent squamous cell carcinoma of the head and neck (SCCHN). AnticancerRes2006; 26:585.

[20] Hitt R, Amador ML, Quintela-Fandino M et a. Weekly Docetaxel in patients with recurrent or metastatic squamous cell carcinoma of head and neck.Cancer2006a,106:106-11

[21] Athanassios A, Ghebremichael M,Gilbert J et al.Phase 3 randomize, placebo controlled trial of Docetaxel with or without Gefitinib in recurrent or metastatic head and neck cancer.An eastern cooperative oncology group trial. J Clin Oncol.2013; 31:1405-14.

Citation: Manas Dubey, Faraz Khan, Rajeev Atri, Vivek Kaushal, Anil $k$ Dhull, Rakesh Dhankhar, Evaluation of TPF versus Gefitinib in Residual or Recurrent or Metastatic $(R / R / M)$ Head and Neck Carcinoma. ARC Journal of Cancer Science. 2019; 5(1):1-6. DOI:dx.doi.org/10.20431/2455-6009.0501001.

Copyright: (C) 2019 Authors. This is an open-access article distributed under the terms of the Creative Commons Attribution License, which permits unrestricted use, distribution, and reproduction in any medium, provided the original author and source are credited. 